Int. J. Morphol.,

24(4):571-774, 2006.

\title{
Principal Component Factor Analysis of the Morphostructure of Immature Uda Sheep
}

\author{
Análisis Factorial de los Principales Componentes de la Morfoestructura de Ovejas Uda Inmaduras \\ Salako, A. E.
}

SALAKO, A. E. Principal component factor analysis of the morphostructure of immature Uda sheep. Int. J. Morphol., 24(4):571-574, 2006.

SUMMARY: Ten body measurements were taken on 30 Uda sheep aged 0-14 months within the humid southwest Nigeria. The body measurements were wither height (WH), body length (BL), rump length (RL), rump height (RH), rump width (RW), foreleg length (FL), shoulder width (SW), face length (FaL), tail length (TL) and heart girth (HG). The aim was to investigate the variance structure and provide an objective description of the body shape (conformation) of the sheep within the first years of life using a cluster analysis. This was possible sequel to the application and permission of the Pearson's correlation coefficient. Applying the traditional use of wither height for size estimation, the animal measured $65.83 \pm 5.81 \mathrm{~cm}$. Other body measurements for that age group were: $\mathrm{BL}=59.37 \pm 4.50$, $\mathrm{RL}=22.1 \pm 1.12, \mathrm{RH}=65.18 \pm 6.06, \mathrm{RW}=12.90 \pm 1.24, \mathrm{FL}=41.62 \pm 2.29, \mathrm{SW}=14.40 \pm 1.45, \mathrm{FaL}=21.47 \pm 1.82, \mathrm{TL}=40.72 \pm 2.71$ and $\mathrm{HG}=71.98 \pm 4.30 \mathrm{~cm}$. Variability was generally high within body measurements. Correlations among body dimensions were positive and significant $(\mathrm{P}<0.05,0.01 ; \mathrm{r}=0.40-0.99)$. The factor solution from Principal component analysis (PCA) produced two clusters after a promax rotation of the transformation matrix. The first and second principal components explained 67.6 and $11.03 \%$ of the generalized variance in body measurements and gave approximately equal emphasis to each variable. The first component contained measurements that are closely associated with bone growth (FL, TL, FaL, RH, WH and BL) while the second one appeared to produce dimensions that are relatively less associated it (RW, SW and RL). The underlying factors are explained.

KEY WORDS: Morphostructure; Uda sheep; Nigeria.

\section{INTRODUCTION}

Production of meat animals concerns growth and development. Patterns of development are useful in the assessment of conformation. Therefore an attempt to measure these parameters in ways other than conventional weighing and grading seems appropriate. Body measurements in addition to weight measurements describes more completely an individual or population than do the conventional methods of weighing and grading. These body measurements have been used at various times for the estimation of weights when live weights are measured alongside these parameters. Body dimensions have been used to indicate breed, origin and relationship through the medium of head measurements (Jewel, 1963) or to indicate size. EAAP and FAO have used wither height for example as a prime indicator of type (Simon and Buchenauer, 1993) More recently, alternative body measurements and indices estimated from various combinations of conventional and non-conventional body parameters not only provide superior guide to weight but are also used as indicators of type and function in domestic animals. (Schwabe \& Hall, 1989; Salako, 2006).

Many workers have used correlations among body parameters to assess the mutual dependence and relationships among the parameters and possibly to implicate the genetic control of certain parts on the same genomic region. Such knowledge may be crucial to the constructive manipulation of measurable parts in an attempt to alter conformation.

Body shapes measured objectively could improve selection for growth by enabling the breeder to recognize early maturing and late maturing animals of different sizes (Brown et al., 1956, 1973, and 1974). Further exploitation of body dimensions could be achieved by grouping them meaningfully. In such case, their evolutionary significance is also studied. 
The Uda sheep is one of largest indigenous sheep varieties of Nigeria and their body measurements and conformation has been little studied. In this light, this investigation is designed to analyse the body parameters of up-to yearling (0-14 months) Uda sheep in their own rights aside from their commonly reported relationship to live weight.For this purpose and in this study, factor analysis, and precisely, the Principal Component Analysis (PCA) is being used as a tool in the assessment of the body shapes. This could be of evolutionary significance as well as permit an understanding of the complex growth process going on among the body dimensions within the yearling age group in the species. Brown et al (1973) has used a principal component analysis of nine linear measurements and weight in an effort to elicit an objective description of different pre-yearling body shapes

\section{MATERIAL AND METHOD}

The data used for this study was generated from 30 Uda sheep extensively managed in flocks in the Northern Nigerian but are transported periodically to the Southern part sheep markets for sale. The ones measured for this investigation were found at the Bodija market in Ibadan.

Uda sheep of 0-14 months of age were considered to be immature, as their first pair of permanent incisors has not erupted. The age range used was according to the method of Wilson and Durkin (1984) for stratifying extensively managed sheep whose actual ages are not known into age- groups for the purpose of research. After the individual age group was confirmed using dentition, ten different body measurements were taken on each live animal. These include: wither height (WH), body length (BL), heart girth (HG), rump height $(\mathrm{RH})$, rump length (RL), rump width (RW), face length (FaL), tail length (TL), foreleg length (FL) and shoulder width (SW). The procedure and anatomical reference points for the respective body measurements are fully described elsewhere in Salako and Ngere (2002)

Statistical analysis: Means and standard deviation, Pearson's correlation among the measurements and finally, factor analysis-PCA were performed in a single step using the Factor programme of the SPSS (1989) statistical package. After the correlation matrix which was the primary data for the PCA analysis was generated, it was inspected for adequate determinant factor, sampling adequacy (Kaiser-Meyer-Olkin test) and sphericity (Battlet's test)

\section{RESULTS AND DISCUSSION}

Morphometric parameters: Results of the descriptive analysis are presented in table 1.It showed that the immature Uda sheep were $65.83 \pm 5.81 \mathrm{~cm}$ tall from the ground. This is an indicator of the size of the animal at that age. The Uda sheep is a bigger animal than either WAD or Yankasa as reported by Salako \& Ngere (2002). The rump height measurement $(65.18 \pm 6.06 \mathrm{~cm})$, being close to the wither measurement suggests that the animal is not sloppy on standing. On the other hand, rump width and shoulder width measurements showed that the animal is wider at the shoulder than at the rump. The animal is a typical tropical breed being taller than long contrary to what obtains in Western meat livestock (Hall, 1991). Large variation within certain measurements suggests absence of selection, or the parts respond more to the environment than others. In particular, heart girth measurements are usually affected by gut fill and are highly variable. Characteristically, face length being a cephalic measurement exhibits very little variability because of its close association with cranial bone. (Table I). The high variability shown by the standard deviation values associated with the measurements can also be a reflection wide variation among actual ages of the used animal sample which was not known. It is also likely that the figures obtained be lower than those reported for the same animal of known actual ages.

Positive and highly significant $(\mathrm{P}<0.05 / 0.01)$ correlation among the measurements suggests high predictability among the measurements although this was not tested. The coefficient ranged from 0.40 (RL/TL) to 0.99 $(\mathrm{WH} / \mathrm{RH})$. The magnitude of the coefficients reflects active growth at this age group in the species. (Table II)

Kaiser-Meyer-Olkin (KMO) measure of sampling adequacy (0.85) revealing the proportion of the variance in the body measurements caused by the underlying factor and the Bartlett's test of sphericity $(\mathrm{P}<0.01)$, communalities (0.61-0.93), which is the explained variance together with the determinant (1.11E-06) obtained from the correlation matrix permitted all body measurements into reasonable factor analysis-PCA. After a high rotation $(>0.5)$ of the component matrix, two principal components were yielded by the factor solution as presented in table 3 . The first principal component comprising seven measurements (FL, TL, FaL RH WH, BL and HG) explained $67.7 \%$ of the generalized variance in the body measurements giving nearly equal emphasis to each body measurement (0.72-0.89) and can be considered as a generalized size factor. In a similar investigation with cattle, Carpenter et al. (1971) reported that $75 \%$ of the generalized variance was explained by the 
Table I: Mean and standard deviation of body measurements of Uda sheep aged 0-14 months. Number of animals=30

\begin{tabular}{lccc}
\hline \multicolumn{1}{c}{ Body measurements } & Mean $(\mathrm{X})$ & Standard deviation & Standard error \\
\hline Wither height & 65.83 & 5.81 & 1.06 \\
Body len gth & 59.37 & 4.50 & 0.82 \\
Heart girth & 71.98 & 4.50 & 0.79 \\
Rump height & 65.18 & 6.06 & 1.01 \\
Rump width & 12.90 & 1.24 & 0.22 \\
Rump length & 22.11 & 1.12 & 0.20 \\
Face length & 21.47 & 1.82 & 0.33 \\
Tail length & 40.72 & 7.71 & 1.40 \\
Foreleg length & 41.62 & 2.29 & 0.42 \\
Shoulder width & 14.40 & 1.45 & 0.26 \\
\hline
\end{tabular}

Table II. Correlations among the body measurements of Uda sheep aged 0-14 months

\begin{tabular}{lllllllllll} 
FL & 1.00 & & & & & & & & & \\
TL & 0.61 & 1.00 & & & & & & & \\
FaL & 0.78 & 0.78 & 1.00 & & & & & & \\
RH & 0.72 & 0.70 & 0.76 & 1.00 & & & & & \\
RL & 0.67 & 0.40 & 0.56 & 0.67 & 1.00 & & & & \\
RW & 0.41 & 0.44 & 0.51 & 0.51 & 0.57 & 1.00 & & & \\
WH & 0,71 & 0.70 & 0.76 & 0.99 & 0.68 & 0.52 & 1.00 & & \\
SW & 0.48 & 0.41 & 0.50 & 0.53 & 0.60 & 0.80 & 0.54 & 1.00 & 0.00 & 1.00 \\
BL & 0.65 & 0.55 & 0.68 & 0.68 & 0.53 & 0.50 & 0.68 & 0.62 & 0.59 \\
HG & 0.71 & 0.72 & 0.84 & 0.72 & 0.64 & 0.68 & 0.72 & 0.70 & B \\
& FL & TL & FaL & RH & RL & RW & WH & SW & BL & HG \\
\hline
\end{tabular}

Determinant $=1.113 \mathrm{E}-06$

All coefficients were significant $(\mathrm{p}<0.05 / 0.01)$

Table III. Rotated Component Matrix of the PCA showing the factor solution.

\begin{tabular}{lcc}
\hline $\begin{array}{l}\text { Body } \\
\text { measurements }\end{array}$ & \multicolumn{1}{c}{$\begin{array}{c}\text { Factors } \\
\text { (Components) }\end{array}$} \\
\hline Foreleg length* & 0.818 & 2 \\
Tail length* & 0.822 & 0.274 \\
Face length* & 0.869 & 0.170 \\
Rump height* & 0.867 & 0.293 \\
Rump length & 0.542 & 0.325 \\
Rump width & 0.241 & 0.564 \\
Wither height* & 0.858 & 0.919 \\
Shoulder width & 0.272 & 0.335 \\
Body length* & 0.640 & 0.927 \\
Heart girth* & 0.707 & 0.467 \\
\hline
\end{tabular}

Extraction Method: Principal Component Analysis.

*Elements of the first component

first factor. The second principal component comprising only three body dimensions (RL, RW and SW) explained only $11.0 \%$ of the generalized variance. Clearly, two major underlying factors are responsible for the observed clusters. (Table 3). These may be related to the different association of each measurement with bone, environmental components or the time taken to reach maturity. These in turn will be expected to change with time/age. More importantly, the elements present in each cluster probably have common genomic sites for their genetic control. In other words, pleiotropic is likely implicated.
SALAKO, A. E. Análisis factorial de los principales componentes de la morfoestructura de ovejas Uda inmaduras. Int. J. Morphol., 24(4):571$574,2006$.

RESUMEN: En 30 ovejas Uda de 0-14 meses de vida de los humedales del Suroeste nigeriano, se realizaron 10 mediciones de su cuerpo. Las medidas fueron las siguientes altura de los miembros (AM), longitud del cuerpo (LC), longitud e caderas (LCd), altura de las caderas (AlCd), ancho de caderas (AnCd), longitud de los miembros anteriores (LMA), ancho de los hombros (AH), longitud de la cara (LDCa), longitud de la cola (LDCo) circunferencia a nivel del corazón (CC). El objetivo fue investigar las variaciones de estructura y proveer una descripción objetiva de la forma del cuerpo de la oveja dentro del primer año de vida utilizando un análisis de grupo. Esto fue posible gracias a la aplicación del coeficiente de correlación de Pearson. Aplicando el usotradicional de altura de los miembros para estimación del tamaño, el animal midió $65.83 \pm 5.81 \mathrm{~cm}$. Otras medidas del cuerpo para el grupo etario fueron: $\mathrm{LC}=59.37 \pm 4.50, \mathrm{LCd}=22.1 \pm 1.12, \mathrm{AlCd}=65.18 \pm 6.06, \mathrm{AnCd}=12.90 \pm 1.24$, $\mathrm{LMA}=41.62 \pm 2.29, \quad \mathrm{AH}=14.40 \pm 1.45, \quad \mathrm{LDCa}=21.47 \pm 1.82$, $\mathrm{LDCo}=40.72 \pm 2.71$ y $\mathrm{CC}=71.98 \pm 4.30 \mathrm{~cm}$. La variabilidad fue generalmente alta dentro de las medidas del cuerpo. Las correlaciones entre las dimensiones del cuerpo fueron positivas y significativas $(\mathrm{P}<0.05$, 0.01; $\mathrm{r}=0.40-0.99)$. La solución del principal componente analizado produjo dos grupos. Los componentes primero y segundo explicaron el 67.6 y $11.03 \%$ de la varianza generalizada en las medidas del cuerpo y dio igual énfasis a cada variable. El primer componente contenía medidas que estaban estrechamente asociadas al crecimiento de los huesos (LMA, LDCo, LDCa, AlCd, AM y LC) mientras que el segundo parece producir dimensiones que son relativamente menos asociadas a ellos (AnCD, AH y LCd).

PALABRAS CLAVE: Morfoestructura; Oveja Uda; Nigeria. 


\section{REFERENCES}

Brown, C. J.; Brown, J. E. \& Butts, W. T. Evaluating relationships among immature measures of size, shape and performance of Beef bulls. II.The relationship between immature measures of size. Shape and feedlot traits in young beef bulls. J. Anim. Sci., 36:1021, 1971.

Brown, C. J.; Brown, J. E. \& Butts, W. T. Evaluating relationships among immature measures of size, shape and performance of Beef bulls. IV. Regression models for predicting postweaning performance of young Hereford and Angus bulls using preweaning measures of size and shape. J. Anim. Sci., 38:12, 1974.

Brown, C. J.; Ray, M. L.; Gifford, W. \& Honea, R. S. Growth and development of Aberdeen Angus cattle. Ark., Agr. Expt. Sta. Bulletin, 571, 1956.

Brown, C. J.; Brown, J. E. \& Butts, W. T. Evaluating relationships among Immature measures of size shape and performance of beef a bull. IV. Regression models for predicting post weaning performance of young Hereford and Angus bulls using preweaning measures of size and shape. J. Anim. Sci., 38:12, 1974.

Brown, C. J.; Brown, J. E. \& Butts, W. T. Evaluating relationships among Immature measure of size, shape and performance of beef bulls. II.The relationships between immature measures of size, shape and feedlot traits in young beef bulls. J. Anim. Sci., 36:1021, 1973.

Carpenter, Jr., J. A.; Fitzhugh, Jr., H. A.; Cartwright, T. C.; Melton, A. A. \& Thomas, R. C. Principal components for size of Hereford cows. J. Anim. Sci., 33:197, 1971.

Hall, S. J. G. Body dimensions of Nigerian cattle, sheep and goats. Anim. Prod., 53:61-9, 1991.

Jewel, P. A. Cattle from British archaeological sites: In A.E. Mourant and F.E. Zeuner (eds) Man and cattle, Royal Anthropological institute, London, 1963.

Salako, A.E. \& Ngere, L. O Application of multifactorial discriminant analysis in the Morphometric structural differentiation of the WAD and Yankasa sheep in the humid southwest Nigeria. Nig. J. Anim. Prod., 29(2):1637, 2002.

Salako A. E. Application of Morphological indices in the assessment of type and function in sheep. Int. J. Morphol., 24(1):13-8, 2006.
Schwabe, A. E. \& Hall, S. J. G. Distokia in nine British breeds of cattle and its relationship to the dimensions of the Dam and calf. The veterinary record, 125:636-89, 1989.

Simon, D. L. \& Buchenauer. Genetic diversity of European livestock breeds; Wageningen.

Statistical Package for Social Sciences-SPSS. New York, Cary, 1989.

Wilson, R.T. \& Durkin, J.W. Age at permanent incisor eruption in indigenous goat and sheep in semi-arid Africa. Livestock Production Science, 11: 451-5, 1984.
Correspondence to:

Dr. Salako, A.E.

Animal breeding and Genetics unit,

Department of Animal Science,

University of Ibadan,

Ibadan

$\mathcal{N I G E R I A ~}$

Email:aesalak@yahoo.com

Received : 17-05-2006

Accepted: 22-09-2006 